\title{
Synthesis, Crystal Structure, and Electrical Properties of a New Molybdylarsenate $\mathrm{LiNa}_{5} \mathrm{~K}_{3} \mathrm{Mo}_{11} \mathrm{As}_{3} \mathrm{O}_{45}$
}

\author{
Hamadi Hamza, Mohamed Faouzi Zid, and Ahmed Driss \\ Laboratoire de Matériaux et Cristallochimie, Faculté des Sciences de Tunis, Université de Tunis El Manar, Manar II, \\ 2092 Tunis, Tunisia \\ Correspondence should be addressed to Hamadi Hamza; hamadi_hamza@hotmail.com
}

Received 29 December 2013; Accepted 24 April 2014; Published 13 July 2014

Academic Editor: Baoyuan Man

Copyright (c) 2014 Hamadi Hamza et al. This is an open access article distributed under the Creative Commons Attribution License, which permits unrestricted use, distribution, and reproduction in any medium, provided the original work is properly cited.

$\mathrm{LiNa}_{5} \mathrm{~K}_{3} \mathrm{Mo}_{11} \mathrm{As}_{3} \mathrm{O}_{45}$ is a new inorganic compound. It was synthesized by a solid state method. The crystal structure has been studied by single crystal X-ray analysis. The $R$-values reached $2.8 \%$. The title compound crystallizes in the triclinic system, space group P-1, with $a=10.550$ (2) $\AA, b=11.723$ (2) $\AA, c=17.469$ (3) $\AA, \alpha=102.35$ (3) $)^{\circ}, \beta=87.61(2)^{\circ}$, and $\gamma=111.03$ (3) $)^{\circ}$. The anionic unit $\left[\mathrm{Mo}_{11} \mathrm{As}_{3} \mathrm{O}_{45}\right]^{9-}$ is formed by nine $\mathrm{MoO}_{6}$ octahedra, two $\mathrm{MoO}_{5}$ trigonal bipyramids, and three AsO $\mathrm{O}_{4}$ tetrahedra. The association of $\left[\mathrm{Mo}_{11} \mathrm{As}_{3} \mathrm{O}_{45}\right]^{9-}$ units, running along [010], leads to a one-dimensional framework. Li, $\mathrm{K}$, and $\mathrm{Na}$ are located in the space surrounding the anionic ribbons. This material was characterized by SEM microscopy, IR spectroscopy, and powder X-ray diffraction. The electrical conductivity was investigated from $528 \mathrm{~K}$ to $673 \mathrm{~K}$ by impedance complex followed by DSC spectroscopy.

\section{Introduction}

The search for new materials, based in arsenic and molybdenum, with an open framework formed by octahedra and tetrahedra showing multiple modes of connections and containing alkali gives a big interest in solid state chemistry [1]. This kind of material shows important energetic property which is the ionic conductivity. We are interested in this field and we have explored the $\mathrm{A}_{2} \mathrm{O}-\mathrm{MoO}_{3}-\mathrm{As}_{2} \mathrm{O}_{5}$ systems $(\mathrm{A}=$ alkali or silver) in which many compounds were characterized: $\mathrm{K}_{2} \mathrm{MoO}_{2}\left(\mathrm{MoO}_{2} \mathrm{As}_{2} \mathrm{O}_{7}\right)_{2}$ [2], $\mathrm{Na}_{2}\left(\mathrm{MoO}_{2}\right)_{3}\left(\mathrm{As}_{2} \mathrm{O}_{7}\right)_{2}$ [3], and $\mathrm{NaAg}_{2} \mathrm{Mo}_{3} \mathrm{O}_{9} \mathrm{AsO}_{4}$ [4]. We have succeeded in the synthesis of a new material $\mathrm{LiNa}_{5} \mathrm{~K}_{3} \mathrm{Mo}_{11} \mathrm{As}_{3} \mathrm{O}_{45}$. It was prepared by a solid state method.

\section{Experimental Details}

2.1. Synthesis. The $\mathrm{LiNa}_{5} \mathrm{~K}_{3} \mathrm{Mo}_{11} \mathrm{As}_{3} \mathrm{O}_{45}$ compound was obtained from a mixture of $\left(\mathrm{NH}_{4}\right)_{2} \mathrm{Mo}_{4} \mathrm{O}_{13}$ (Fluka 69858), $\mathrm{NH}_{4} \mathrm{H}_{2} \mathrm{AsO}_{4}$ (ASTM 01-775), $\mathrm{Na}_{2} \mathrm{CO}_{3}$ (Prolabo 27778), $\mathrm{K}_{2} \mathrm{CO}_{3}$ (Pan 121490) and $\mathrm{LiOH} \cdot \mathrm{H}_{2} \mathrm{O}$ (Fluka 62530). The mixture was grinded and preheated in air at $673 \mathrm{~K}$ to remove $\mathrm{NH}_{3}, \mathrm{H}_{2} \mathrm{O}$, and $\mathrm{CO}_{2}$. Then, it was grinded and heated again to $808 \mathrm{~K}$. The mixture was left at this temperature for 2 weeks to promote germination and growth of crystals. The final residue was subjected at a first slow cooling $(5 \mathrm{~K} / 24 \mathrm{~h})$ in an interval of $50 \mathrm{~K}$ and then at a second faster cooling $(50 \mathrm{~K} / \mathrm{h})$ to reach room temperature. The yellowish crystals obtained by spontaneous crystallization were separated by flow of hot water to do the preliminary identification.

2.2. Single Crystal X-Ray Data Collection. It was performed with a CAD-4 Enraf-Nonius X-ray diffractometer [5] at $298 \mathrm{~K}$ with graphite monochromator using $\mathrm{MoK}_{\alpha}$ wavelength. All calculations were performed using the Wingx-98 crystallographic software package [6]. An empirical correction of absorption by PSI scan [7] was applied. The structure was solved and refined using, respectively, SHELXS-97 and SHELXL-97 [8] by full-matrix least squares based on $F^{2}$. The graphs of the structure were drawn with diamond 2.1 supplied by Crystal Impact [9]. The crystal data and the refinements details are summarized in Table 1. Table 2 contains the main bond distances.

2.3. Powder XRD Analysis. The polycrystalline powder was prepared from a stoichiometric mixture of reagents forming the single crystal. In the beginning, the mixture was heated 
TABLE 1: Crystal data and the refinements details.

\begin{tabular}{lc}
\hline Empirical formula & $\mathrm{LiNa}_{5} \mathrm{~K}_{3} \mathrm{Mo}_{11} \mathrm{As}_{3} \mathrm{O}_{45}$ \\
Crystal system/space group/Z & Triclinic/P-1/2 \\
$a(\AA)$ & $10.550(2)$ \\
$b(\AA)$ & $11.723(2)$ \\
$c(\AA)$ & $17.469(3)$ \\
$\alpha\left(^{\circ}\right)$ & $102.35(3)$ \\
$\beta\left(^{\circ}\right)$ & $87.61(2)$ \\
$\gamma\left(^{\circ}\right)$ & $111.03(3)$ \\
$V\left(\AA^{3}\right) Z$ & $1986.46(2)$ \\
$\mu\left(\mathrm{mm}^{-1}\right)$ & 6.39 \\
$\rho_{x}\left(\mathrm{~g} \cdot \mathrm{cm}^{-3}\right) /$ formula weight $(\mathrm{g} / \mathrm{mol})$ & $3.78 / 2247.34$ \\
Crystal size $(\mathrm{mm}) /$ Color & $0.2 \times 0.5 /$ yellow \\
Tmin/Tmax & $0.7026 / 0.8745$ \\
Measured reflections & 9789 \\
Independent reflections/rint & $8557 / 0.0157$ \\
Observed refl. with $I>2 \sigma(I)$ & 7730 \\
Data/restraints/parameters & $8557 / 2 / 619$ \\
$R\left[F^{2}>2 \sigma\left(F^{2}\right)\right]$ & 0.028 \\
$w R\left(F^{2}\right) / S / F(000)$ & $0.071 / 1.22 / 2072$ \\
$\Delta \rho$ max $/ \Delta \rho$ min $\left(\mathrm{e} \cdot \AA^{-3}\right)$ & $1.56 /-1.39$ \\
\hline
\end{tabular}

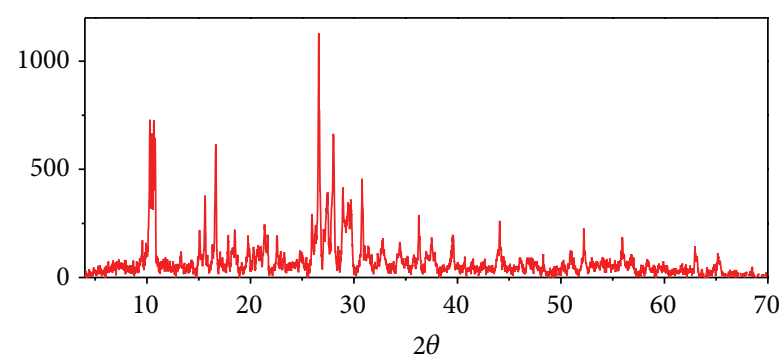

Figure 1: Experimental XRD pattern of $\mathrm{LiNa}_{5} \mathrm{~K}_{3} \mathrm{Mo}_{11} \mathrm{As}_{3} \mathrm{O}_{45}$.

at $473 \mathrm{~K}$ to remove volatile compounds. Then, it was grinded and heated to $673 \mathrm{~K}$ and it was rigorously grinded again before heating up to $773 \mathrm{~K}$. The residue was maintained for 48 hours at this temperature. Then, it was cooled down rapidly to room temperature. Obtained powder was characterized using $\mathrm{X}$-ray diffraction. XRD analysis was performed with a PANalytical X'PertPro diffractometer with $\mathrm{CuK} \alpha$ radiation $(\lambda=$ $1.5406 \AA$ ). The comparison of obtained pattern (Figure 1) with reference pattern (Figure 2) shows that powder is pure. The obtained pattern was indexed in Table 3 by the programs X'pert Highscore plus [10] and Diamond 3.2 [11].

The confidence factor calculated by the formula $\sum\left(\mid 2 \theta_{\text {cal }}-\right.$ $\left.2 \theta_{\exp } \mid\right) / \sum n i$ is $1.27 \%$.

2.4. Scanning Electron Microscopy. One single crystal was selected by means of polarizing microscope. Then, it was analyzed by dispersive energy spectroscopy (model FEI type Quanta 200). The SEM analysis was used to observe the crystal morphology (Figure 3). The EDS local microanalysis (Figure 4) confirms the presence of expected chemical
TABLE 2: Main bond distances.

\begin{tabular}{|c|c|c|c|}
\hline \multicolumn{4}{|c|}{ Bond distances $(\AA)$} \\
\hline As1-O30 & $1.669(4)$ & Mo10-O9 & $2.313(4)$ \\
\hline As1-O25 & $1.677(4)$ & Mo10-O14 & $2.360(4)$ \\
\hline As1-O9 & $1.691(4)$ & Mo11-O39 & $1.707(4)$ \\
\hline As1-O10 & $1.696(4)$ & Moll-O45 $5^{\mathrm{iii}}$ & $1.714(5)$ \\
\hline As2-O15 $5^{\mathrm{iii}}$ & $1.663(4)$ & Mol1-O21 & $1.835(4)$ \\
\hline As2-O24 & $1.679(4)$ & Mo11-O35 & $1.915(4)$ \\
\hline As2-O13 & $1.690(4)$ & Mo11-O37 & $2.285(4)$ \\
\hline As2-O37 & $1.695(4)$ & K1-O41 & $2.751(4)$ \\
\hline As3-O23 & $1.675(4)$ & $\mathrm{K} 1-\mathrm{O} 38^{\mathrm{vi}}$ & $2.759(4)$ \\
\hline As3-O20 & $1.677(4)$ & $\mathrm{K} 1-\mathrm{O} 12^{\mathrm{i}}$ & $2.802(4)$ \\
\hline As3-O14 & $1.698(4)$ & $\mathrm{K} 1-\mathrm{O} 17^{\mathrm{vii}}$ & $2.823(4)$ \\
\hline As3-O4 & $1.699(4)$ & $\mathrm{K} 1-\mathrm{O} 43^{\mathrm{vii}}$ & $2.906(4)$ \\
\hline Mo1-O28 & $1.701(4)$ & K1-O15 & $2.912(4)$ \\
\hline Mo1-O26 & $1.731(4)$ & $\mathrm{K} 1-\mathrm{O} 17^{\mathrm{i}}$ & $2.958(5)$ \\
\hline Mol-O6 & $1.826(4)$ & K1-O5 & $3.115(4)$ \\
\hline Mo1-O19 & $1.923(4)$ & K2-O7 & $2.755(4)$ \\
\hline Mo1-O10 & $2.273(4)$ & $\mathrm{K} 2-\mathrm{O} 28^{\mathrm{v}}$ & $2.770(4)$ \\
\hline Mo2-O22 & $1.706(4)$ & $\mathrm{K} 2-\mathrm{O} 34^{\mathrm{v}}$ & $2.803(4)$ \\
\hline Mo2-O41 & $1.735(4)$ & $\mathrm{K} 2-\mathrm{O} 32^{\mathrm{x}}$ & $2.852(4)$ \\
\hline Mo2-O5 & $1.869(4)$ & $\mathrm{K} 2-\mathrm{O} 45$ & $2.867(5)$ \\
\hline Mo2-O18 ${ }^{\mathrm{i}}$ & $1.972(4)$ & K2-O1 & $2.932(5)$ \\
\hline Mo2-O30 & $2.217(4)$ & $\mathrm{K} 2-\mathrm{O} 31^{\mathrm{i}}$ & $2.979(5)$ \\
\hline Mo2-O14 & $2.285(4)$ & $\mathrm{K} 2-\mathrm{O} 20$ & $3.019(4)$ \\
\hline $\mathrm{Mo3}-\mathrm{O} 16^{\mathrm{ii}}$ & $1.685(4)$ & K3-O29 & $2.615(4)$ \\
\hline Mo3-O32 & $1.724(4)$ & $\mathrm{K} 3-\mathrm{O} 2^{\mathrm{vii}}$ & $2.713(4)$ \\
\hline Mo3-O29 & $1.943(4)$ & K3-O33 & $2.726(4)$ \\
\hline Mo3-O19 & $1.972(4)$ & $\mathrm{K} 3-\mathrm{O} 22^{\mathrm{vii}}$ & $2.932(5)$ \\
\hline Mo3-O24 & $2.239(4)$ & $\mathrm{K} 3-\mathrm{O} 36^{\mathrm{ii}}$ & $2.964(4)$ \\
\hline Mo3-O10 & $2.266(4)$ & $\mathrm{K} 3-\mathrm{O} 30$ & $3.063(4)$ \\
\hline Mo4-O11 & $1.700(4)$ & Nal-O4 & $2.409(4)$ \\
\hline Mo4-O40 & $1.731(4)$ & $\mathrm{Nal}-\mathrm{O} 32$ & $2.444(5)$ \\
\hline Mo4-O8 & $1.916(4)$ & $\mathrm{Nal}-\mathrm{O} 11^{\mathrm{i}}$ & $2.522(5)$ \\
\hline Mo4-O3 $3^{\mathrm{iii}}$ & $1.924(4)$ & $\mathrm{Na1}-\mathrm{O} 26$ & $2.530(5)$ \\
\hline Mo4-O4 $4^{\mathrm{iii}}$ & $2.263(4)$ & $\mathrm{Na}-\mathrm{O} 33$ & $2.608(5)$ \\
\hline Mo4-O13 & $2.317(4)$ & Na1-O10 & $2.719(5)$ \\
\hline Mo5-O38 $8^{\mathrm{ii}}$ & $1.705(4)$ & $\mathrm{Na} 1-\mathrm{O} 23$ & $2.861(5)$ \\
\hline Mo5-O33 & $1.714(4)$ & Na1-O30 & $2.995(5)$ \\
\hline Mo5-O5 & $1.918(4)$ & $\mathrm{Na} 2-\mathrm{O} 43$ & $2.400(6)$ \\
\hline Mo5-O8 ${ }^{\mathrm{i}}$ & $1.943(4)$ & $\mathrm{Na} 2-\mathrm{O} 18^{\mathrm{i}}$ & $2.468(5)$ \\
\hline Mo5-O15 & $2.205(4)$ & $\mathrm{Na} 2-\mathrm{O} 41^{\text {viii }}$ & $2.521(5)$ \\
\hline Mo5-O4 & $2.308(4)$ & $\mathrm{Na} 2-\mathrm{O} 22$ & $2.642(5)$ \\
\hline Mo6-O1 & $1.702(5)$ & $\mathrm{Na} 2-\mathrm{O} 44^{\mathrm{viii}}$ & $2.710(6)$ \\
\hline Mo6-O27 & $1.710(4)$ & $\mathrm{Na} 2-\mathrm{O} 2$ & $2.812(6)$ \\
\hline Mo6-O7 & $1.936(4)$ & $\mathrm{Na} 2-\mathrm{O} 25$ & $2.882(5)$ \\
\hline Mo6-O6 & $1.963(4)$ & $\mathrm{Na} 3-\mathrm{O} 40^{\mathrm{xi}}$ & $2.483(4)$ \\
\hline Mo6-O9 & $2.220(4)$ & Na3-O1 & $2.527(6)$ \\
\hline Mo6-O23 & $2.237(4)$ & $\mathrm{Na} 3-\mathrm{O} 39^{\mathrm{v}}$ & $2.628(5)$ \\
\hline Mo7-O17 & $1.697(4)$ & Na3-O3 & $2.737(4)$ \\
\hline Mo7-O2 & $1.710(4)$ & $\mathrm{Na} 3-\mathrm{O} 27^{\mathrm{v}}$ & $2.749(5)$ \\
\hline
\end{tabular}


TABLE 2: Continued.

\begin{tabular}{|c|c|c|c|}
\hline \multicolumn{4}{|c|}{ Bond distances $(\AA)$} \\
\hline Mo7-O29 & $1.922(4)$ & $\mathrm{Na} 3-\mathrm{O} 31^{\mathrm{i}}$ & $2.786(5)$ \\
\hline Mo7-O12 & $1.964(4)$ & $\mathrm{Na} 3-\mathrm{O} 23$ & $2.845(4)$ \\
\hline Mo7-O24 & $2.252(4)$ & $\mathrm{Na} 4-\mathrm{O} 14$ & $2.313(5)$ \\
\hline Mo7-O25 & $2.280(4)$ & $\mathrm{Na} 4-\mathrm{O} 36$ & $2.401(6)$ \\
\hline Mo8-O43 & $1.712(4)$ & $\mathrm{Na} 4-\mathrm{O} 44$ & $2.412(6)$ \\
\hline Mo8-O44 & $1.712(4)$ & $\mathrm{Na} 4-\mathrm{O} 45$ & $2.416(6)$ \\
\hline Mo8-O12 & $1.889(4)$ & $\mathrm{Na} 4-\mathrm{O} 37^{\mathrm{i}}$ & $2.436(5)$ \\
\hline Mo8-O35 & $1.933(4)$ & $\mathrm{Na} 4-\mathrm{O} 20$ & $2.671(5)$ \\
\hline Mo8-O37 & $2.301(4)$ & $\mathrm{Na} 4-\mathrm{O} 41$ & $2.910(6)$ \\
\hline Mo8-O25 & $2.450(4)$ & $\mathrm{Na} 5-\mathrm{O} 16$ & $2.373(5)$ \\
\hline Mo9-O31 & $1.702(4)$ & $\mathrm{Na} 5-\mathrm{O} 8^{\mathrm{x}}$ & $2.401(4)$ \\
\hline Mo9-O34 & $1.721(4)$ & $\mathrm{Na} 5-\mathrm{O} 27$ & $2.439(6)$ \\
\hline Mo9-O3 ${ }^{\mathrm{iii}}$ & $1.929(4)$ & $\mathrm{Na} 5-\mathrm{O} 42$ & $2.468(5)$ \\
\hline Mo9-O21 & $1.949(4)$ & Na5-O35 & $2.474(5)$ \\
\hline Mo9-O20 ${ }^{\mathrm{iii}}$ & $2.224(4)$ & $\mathrm{Na} 5-\mathrm{O} 39$ & $2.734(5)$ \\
\hline Mo9-O13 & $2.227(4)$ & $\mathrm{Li}-\mathrm{O} 19$ & $2.037(12)$ \\
\hline Mo10-O42 & $1.710(4)$ & $\mathrm{Li}-\mathrm{O} 40$ & $2.041(12)$ \\
\hline Mo10-O36 & $1.725(4)$ & $\mathrm{Li}-\mathrm{O} 34$ & $2.053(13)$ \\
\hline Mo10-O18 ${ }^{\mathrm{i}}$ & $1.894(4)$ & $\mathrm{Li}-\mathrm{O} 26^{\mathrm{xi}}$ & $2.075(12)$ \\
\hline Mo10-O7 & $1.927(4)$ & & \\
\hline
\end{tabular}

Symmetry codes:(i) $\mathrm{x}, \mathrm{y}-1, \mathrm{z}$; (ii) $\mathrm{x}-1, \mathrm{y}, \mathrm{z}$;(iii) $\mathrm{x}, \mathrm{y}+1, \mathrm{z}$; (iv) $\mathrm{x}-1, \mathrm{y}-1, \mathrm{z}$; (v) $-\mathrm{x}+1$, $-\mathrm{y}+1,-\mathrm{z}$; (vi) $-\mathrm{x}+1,-\mathrm{y},-\mathrm{z}+1$; (vii) $-\mathrm{x},-\mathrm{y}+1,-\mathrm{z}+1$; (viii) $-\mathrm{x}+1,-\mathrm{y}+1,-\mathrm{z}+1$; (ix) $-x,-y,-z+1$; (x) $x+1, y, z ;(x i)-x,-y+1,-z$; (xii) $x+1, y+1, z$.

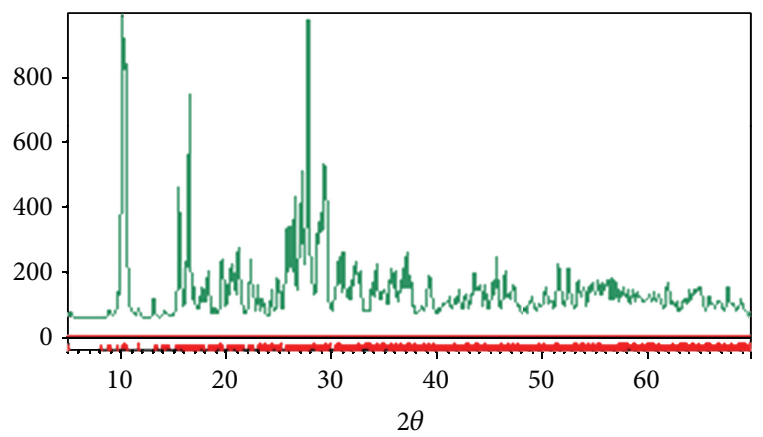

Figure 2: Calculated XRD pattern of $\mathrm{LiNa}_{5} \mathrm{~K}_{3} \mathrm{Mo}_{11} \mathrm{As}_{3} \mathrm{O}_{45}$.

elements, particularly: sodium, potassium, molybdenum, arsenic, and oxygen.

2.5. Infrared Spectroscopy FTIR. For this analysis, sample was prepared from a mixture of $2 \mathrm{mg}$ of pure powder of $\mathrm{LiNa}_{5} \mathrm{~K}_{3} \mathrm{Mo}_{11} \mathrm{As}_{3} \mathrm{O}_{45}$ and $200 \mathrm{mg}$ of $\mathrm{KBr}$ and compressed with hydraulic press under $100 \mathrm{~kg} / \mathrm{cm}^{2}$ in order to obtain a little pellet. In the transmission spectrum (Figure 5) obtained by spectrometer model Nicolet-IR 200, we have found two main strong and well-resolved bands around 490 and $830 \mathrm{~cm}^{-1}$ characterizing, respectively, the stretching of $\mathrm{MoO}_{6}$ $[12,13]$ and $\mathrm{AsO}_{4}[14]$ and two absorption bands at 425 and $625 \mathrm{~cm}^{-1}$ arising from the vibration of $\mathrm{MoO}_{6}$ [15]. A peak around $952 \mathrm{~cm}^{-1}$ might be assigned to the stretching and
TABLE 3: Indexation of powder XRD pattern.

\begin{tabular}{|c|c|c|c|c|c|}
\hline$h$ & $k$ & $l$ & $I / I_{0} \%$ & $2 \theta_{\text {ref }}\left({ }^{\circ}\right)$ & $2 \theta_{\exp }\left({ }^{\circ}\right)$ \\
\hline-1 & 1 & 0 & 6.4 & 09.786 & 09.791 \\
\hline-1 & 0 & 1 & 100 & 10.196 & 10.199 \\
\hline 0 & 0 & 2 & 77.8 & 10.367 & 10.369 \\
\hline 1 & -2 & 1 & 49.9 & 15.567 & 15.621 \\
\hline-1 & 2 & 0 & 11.8 & 15.764 & 15.758 \\
\hline 0 & 2 & 0 & 87 & 16.571 & 16.574 \\
\hline-1 & 0 & 3 & 11.4 & 17.703 & 17.696 \\
\hline 1 & 0 & 3 & 10.9 & 18.309 & 18.308 \\
\hline 0 & 2 & 1 & 10.2 & 18.409 & 18.393 \\
\hline-1 & 2 & 2 & 16.2 & 20.603 & 20.620 \\
\hline 2 & 0 & 2 & 12.8 & 21.177 & 21.113 \\
\hline-1 & -2 & 1 & 14.4 & 21.243 & 21.249 \\
\hline 2 & 1 & 0 & 13.1 & 22.420 & 22.422 \\
\hline 1 & 2 & 1 & 11.9 & 23.096 & 23.090 \\
\hline 3 & -1 & 1 & 30.1 & 25.758 & 25.754 \\
\hline 2 & -1 & 4 & 16.4 & 26.075 & 26.077 \\
\hline 2 & -2 & 4 & 15.8 & 26.574 & 26.608 \\
\hline-2 & 1 & 4 & 41.3 & 27.783 & 27.777 \\
\hline-1 & -1 & 5 & 45.5 & 27.890 & 27.896 \\
\hline-1 & 2 & 4 & 19.6 & 28.713 & 28.712 \\
\hline-1 & -3 & 1 & 19.9 & 28.976 & 28.890 \\
\hline-2 & -2 & 2 & 8.2 & 29.067 & 29.069 \\
\hline-3 & 2 & 2 & 7.1 & 29.246 & 29.256 \\
\hline-1 & -3 & 2 & 25.6 & 29.372 & 29.466 \\
\hline 2 & -3 & 4 & 22.9 & 29.573 & 29.579 \\
\hline-2 & -2 & 3 & 13.7 & 30.651 & 30.650 \\
\hline-3 & -1 & 1 & 10.9 & 31.199 & 31.194 \\
\hline 0 & 3 & 3 & 11.5 & 32.348 & 32.333 \\
\hline 3 & -4 & 1 & 10.8 & 34.308 & 34.305 \\
\hline 3 & -4 & 3 & 11.3 & 35.677 & 35.682 \\
\hline-3 & 1 & 5 & 11.5 & 37.266 & 37.263 \\
\hline-1 & -1 & 7 & 10.9 & 37.577 & 37.523 \\
\hline-3 & -1 & 5 & 4.8 & 39.189 & 39.184 \\
\hline 2 & -2 & 8 & 5.9 & 44.250 & 44.251 \\
\hline 4 & -3 & 6 & 12.6 & 45.773 & 45.780 \\
\hline-1 & -5 & 4 & 2.4 & 47.146 & 47.140 \\
\hline 2 & -5 & 8 & 2.7 & 52.161 & 52.155 \\
\hline-1 & 2 & 9 & 0.8 & 54.077 & 54.076 \\
\hline 5 & -3 & 7 & 2.5 & 55.893 & 55.895 \\
\hline-4 & -4 & 1 & 6.5 & 58.832 & 58.836 \\
\hline 4 & 0 & 9 & 2.4 & 63.020 & 63.018 \\
\hline 2 & -8 & 5 & 2.7 & 65.199 & 65.194 \\
\hline
\end{tabular}

the bending of $\mathrm{AsO}_{4}$ [14] and little band, at $995 \mathrm{~cm}^{-1}$, is the result of the vibration of $\mathrm{MoO}_{5}[12,16]$.

2.6. Complex Impedance Analysis. The electrical properties of the $\mathrm{LiNa}_{5} \mathrm{~K}_{3} \mathrm{Mo}_{11} \mathrm{As}_{3} \mathrm{O}_{45}$ material have been investigated using complex impedance spectroscopy. The sample is prepared by pressing the crystal powder at $100 \mathrm{~kg} / \mathrm{cm}^{2}$ and sintering at $673 \mathrm{~K}$ for 24 hours. The thickness and the surface of 


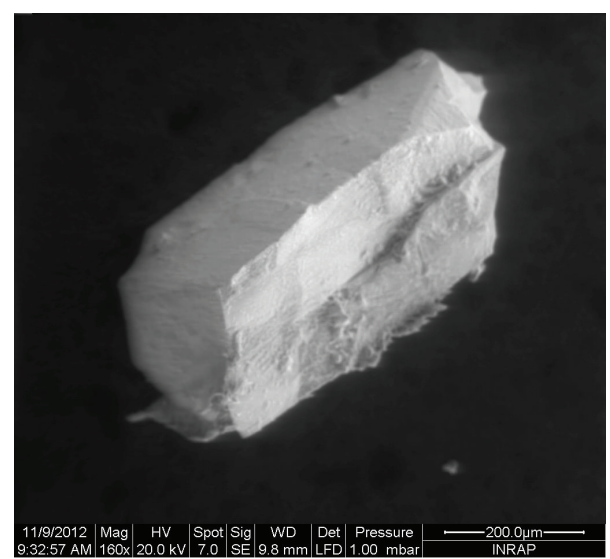

FIgURE 3: Crystal morphology.

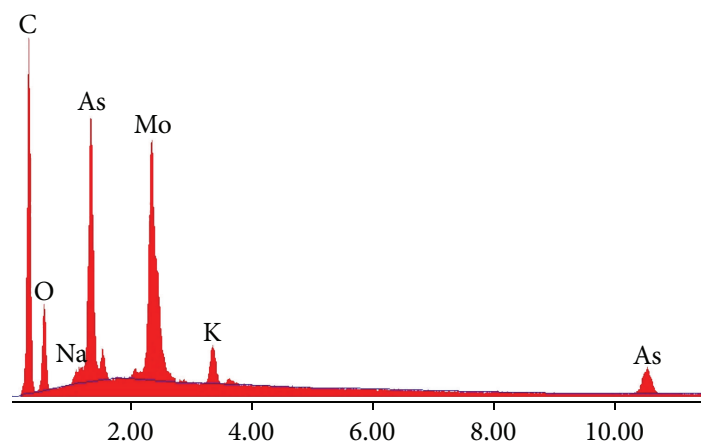

FIGURE 4: EDS analysis spectrum.

the obtained pellet are respectively, $0.136 \mathrm{~cm}$ and $1.40 \mathrm{~cm}^{2}$. This pellet was placed between two blocking platinum electrodes in order to ensure good electric contacts in a tubular oven to undergo the measurements of complex impedance by using a Hewlett-Packard 4192-A impedance analyzer in the temperature range from $523 \mathrm{~K}$ to $673 \mathrm{~K}$ and in the frequency range from $5 \mathrm{~Hz}$ to $13000 \mathrm{~Hz}$.

2.7. Differential Scanning Calorimetric Analysis. To examine thermal transitions in $\mathrm{LiNa}_{5} \mathrm{~K}_{3} \mathrm{Mo}_{11} \mathrm{As}_{3} \mathrm{O}_{45}$ compound, a sample of $10.3 \mathrm{mg}$ was analyzed by using a differential scanning calorimeter 822 -E made by Mettler Toledo.

\section{Results and Discussion}

3.1. Structure Description. The asymmetric unit of $\mathrm{LiNa}_{5} \mathrm{~K}_{3} \mathrm{Mo}_{11} \mathrm{As}_{3} \mathrm{O}_{45}$ compound (Figure 6) consists of

(i) three $\mathrm{Mo}_{3} \mathrm{O}_{14}$ motifs; each one is formed by three octahedra sharing edges;

(ii) two $\mathrm{MoO}_{5}$ bipyramids which are inserted between the three $\mathrm{Mo}_{3} \mathrm{O}_{14}$ motifs. They are linked by edges and corners;

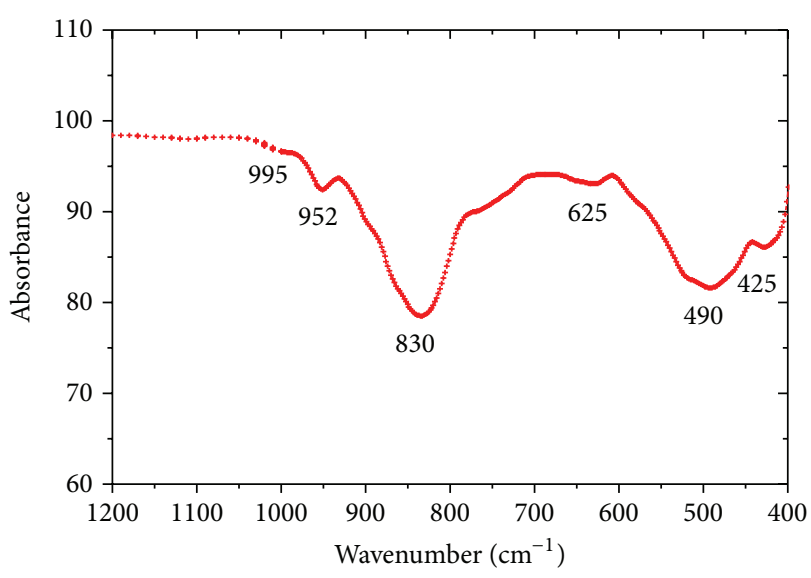

FIgURE 5: IR spectrum of $\mathrm{LiNa}_{5} \mathrm{~K}_{3} \mathrm{Mo}_{11} \mathrm{As}_{3} \mathrm{O}_{45}$.

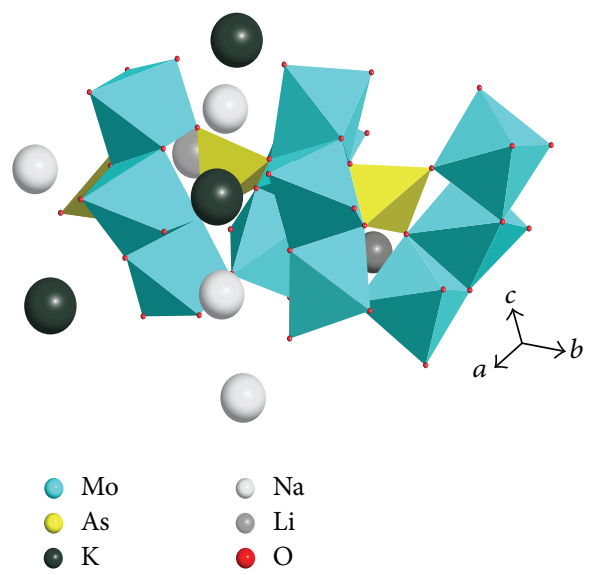

FIGURE 6: The asymmetric unit.

(iii) three $\mathrm{AsO}_{4}$ tetrahedra; each one is linked by sharing corners with four octahedra.

The association of two $\mathrm{MoO}_{5}$ bipyramids and one $\mathrm{Mo}_{3} \mathrm{O}_{14}$ motif leads to a $\mathrm{Mo}_{5} \mathrm{O}_{20}$ semicyclic group.

The charge compensation is ensured by $\mathrm{Na}^{+}, \mathrm{K}^{+}$, and $\mathrm{Li}^{+}$. The molybdenum atom Mo (11) is delocalized. It occupies two positions with the distance of 0.949 (8) $\AA$ with various occupancies $93.3 \%$ and $6.7 \%$.

The combination of asymmetric units by sharing corners between octahedra and tetrahedra leads to $\left(\mathrm{Mo}_{11} \mathrm{As}_{3} \mathrm{O}_{45}\right)^{9-}$ ribbons (Figure 7). The structure of $\mathrm{LiNa}_{5} \mathrm{~K}_{3} \mathrm{Mo}_{11} \mathrm{As}_{3} \mathrm{O}_{45} \mathrm{can}$ be described as a one-dimensional framework of ribbons disposed along [010] direction. $\mathrm{Na}^{+}, \mathrm{K}^{+}$, and $\mathrm{Li}^{+}$are situated in the space surrounding the ribbons (Figures 8 and 9).

In the structure of $\mathrm{LiNa}_{5} \mathrm{~K}_{3} \mathrm{Mo}_{11} \mathrm{As}_{3} \mathrm{O}_{45}$, the polyhedra are distorted because of the existence of

(i) short atomic bonds of molybdenyl group in $\mathrm{MoO}_{6}$ octahedra and $\mathrm{MoO}_{5}$ bipyramids;

(ii) short atomic bonds in $\mathrm{AsO}_{4}$ tetrahedra. 


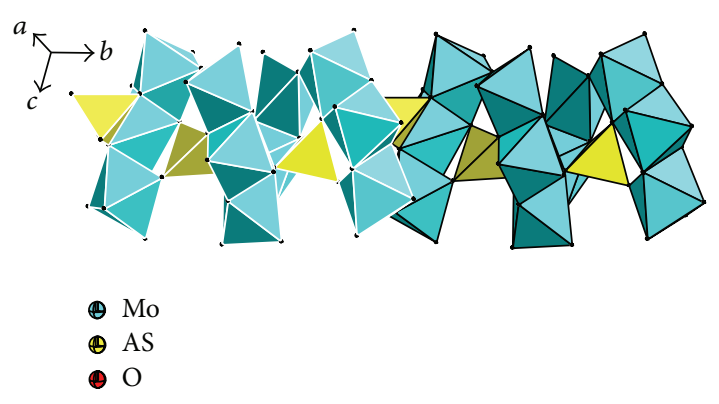

Figure 7: View of $\left(\mathrm{Mo}_{11} \mathrm{As}_{3} \mathrm{O}_{45}\right)^{9-}$ ribbon.

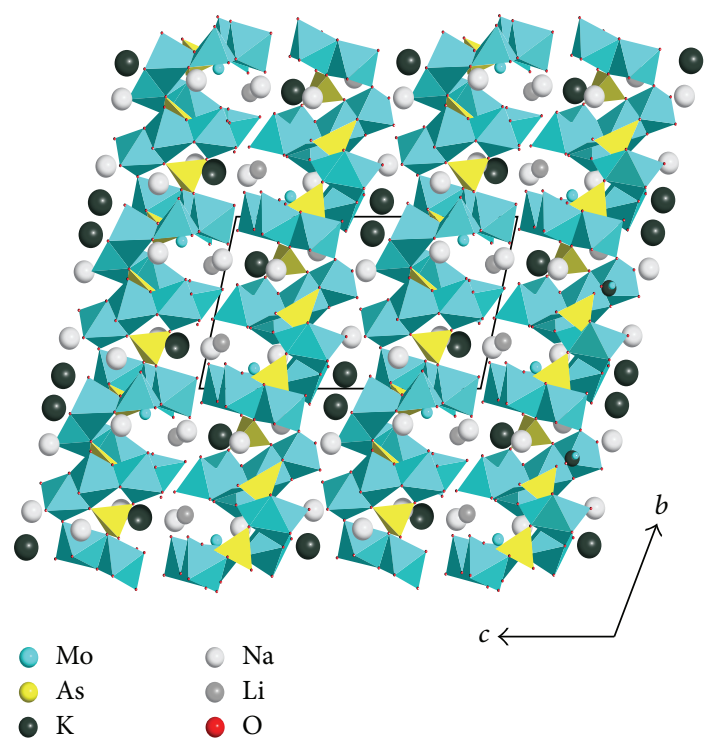

Figure 8: Projection of the structure of $\mathrm{LiNa}_{5} \mathrm{~K}_{3} \mathrm{Mo}_{11} \mathrm{As}_{3} \mathrm{O}_{45}$.

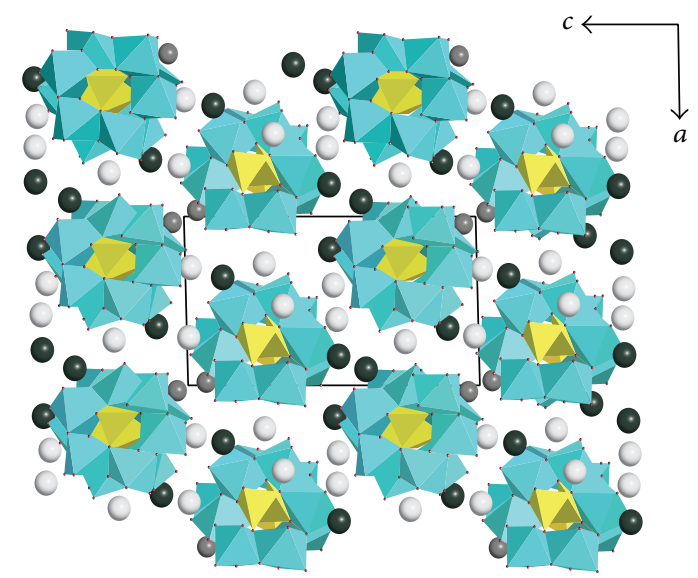
○ Mo
C $\mathrm{Na}$
- As
○ $\mathrm{Li}$
- $\mathrm{K}$
- $\mathrm{O}$

Figure 9: Projection of the structure along [010].

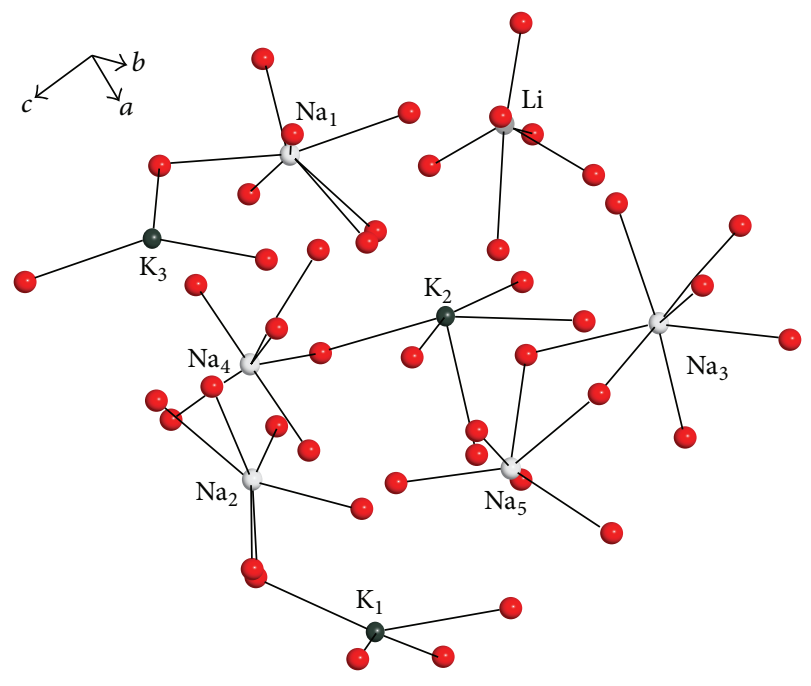

Figure 10: Arrangements of cations.

TABle 4: Angles and distances distortion factors (\%).

\begin{tabular}{lcc}
\hline Polyhedra & $\mathrm{D}_{d} \mathrm{~F}$ & $\mathrm{~A}_{d} \mathrm{~F}$ \\
\hline $\mathrm{As}(1)-\mathrm{O}_{4}$ & 0.15 & 2.33 \\
$\mathrm{As}(2)-\mathrm{O}_{4}$ & 0.15 & 2.54 \\
$\mathrm{As}(3)-\mathrm{O}_{4}$ & 0.16 & 3.70 \\
$\mathrm{Mo}(1)-\mathrm{O}_{5}$ & 1.75 & 13.64 \\
$\mathrm{Mo}(2)-\mathrm{O}_{6}$ & 1.64 & 7.49 \\
$\mathrm{Mo}(3)-\mathrm{O}_{6}$ & 1.58 & 8.45 \\
$\mathrm{Mo}(4)-\mathrm{O}_{6}$ & 1.77 & 9.39 \\
$\mathrm{Mo}(5)-\mathrm{O}_{6}$ & 1.64 & 8.25 \\
$\mathrm{Mo}(6)-\mathrm{O}_{6}$ & 1.51 & 10.61 \\
$\mathrm{Mo}(7)-\mathrm{O}_{5}$ & 1.66 & 9.03 \\
$\mathrm{Mo}(8)-\mathrm{O}_{6}$ & 2.09 & 9.37 \\
$\mathrm{Mo}(9)-\mathrm{O}_{6}$ & 1.51 & 7.49 \\
$\mathrm{Mo}(10)-\mathrm{O}_{6}$ & 1.94 & 9.79 \\
$\mathrm{Mo}(11)-\mathrm{O}_{6}$ & 1.76 & 9.29 \\
\hline
\end{tabular}

The distortion factors of angles and distances of atomic bonds (resp., $\mathrm{A}_{d} \mathrm{~F}$ and $\mathrm{D}_{d} \mathrm{~F}$ ), obtained by the following formula, are summarized in Table 4:

$$
\begin{gathered}
\mathrm{D}_{d} \mathrm{~F}=\left[\frac{\sum\left(\left|d_{i}-d_{m}\right|\right)}{n_{1} \cdot d_{m}}\right], \\
\mathrm{A}_{d} \mathrm{~F}=\left[\frac{\sum\left(\left|a_{i}-a_{m}\right|\right)}{n_{2} \cdot a_{m}}\right]
\end{gathered}
$$

(see [17]). $d_{i}$ is real distance value, $d_{m}$ is moyen distance value, $n_{1}$ is coordination number, $a_{i}$ is real angle value, $a_{m}$ is moyen angle value, and $n_{2}$ is angles number.

Moreover, the calculation of the various valence sums of atomic bonds (BVS), using empirical formula of Altermatt and Brown [18], confirms that they are the expected values of ions charges. All bond valence sums are represented in Table 5. 


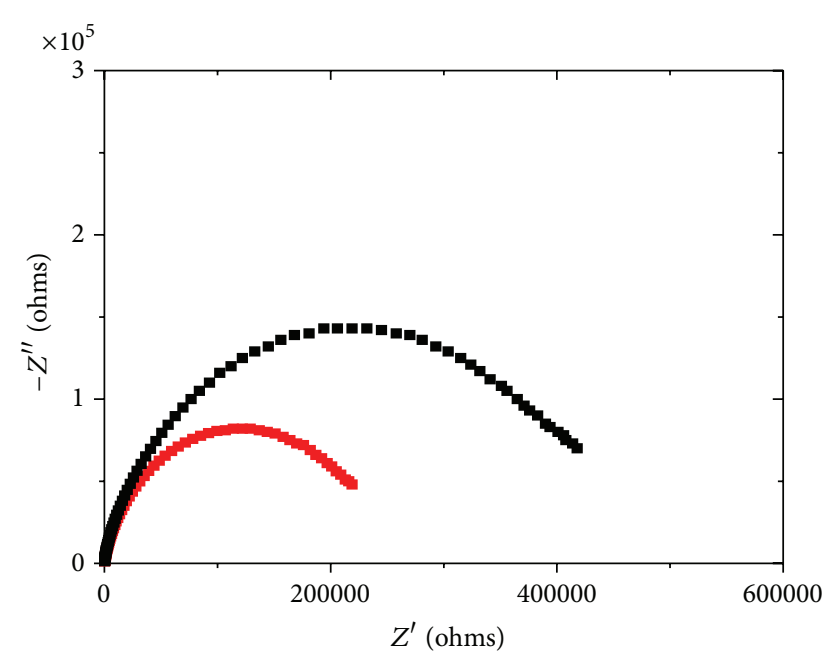

- $255^{\circ} \mathrm{C}$

- $280^{\circ} \mathrm{C}$

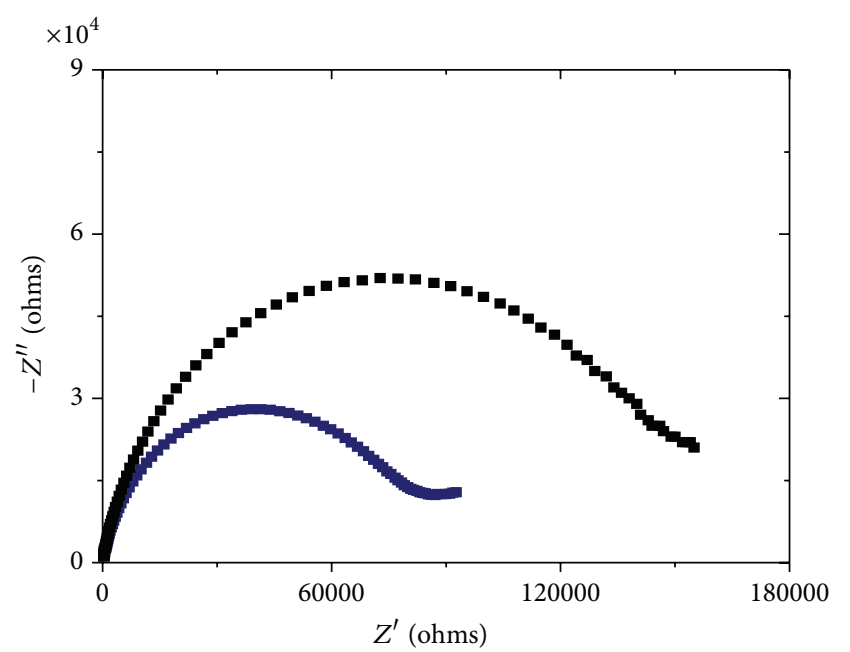

- $310^{\circ} \mathrm{C}$

- $340^{\circ} \mathrm{C}$

(a)

(b)

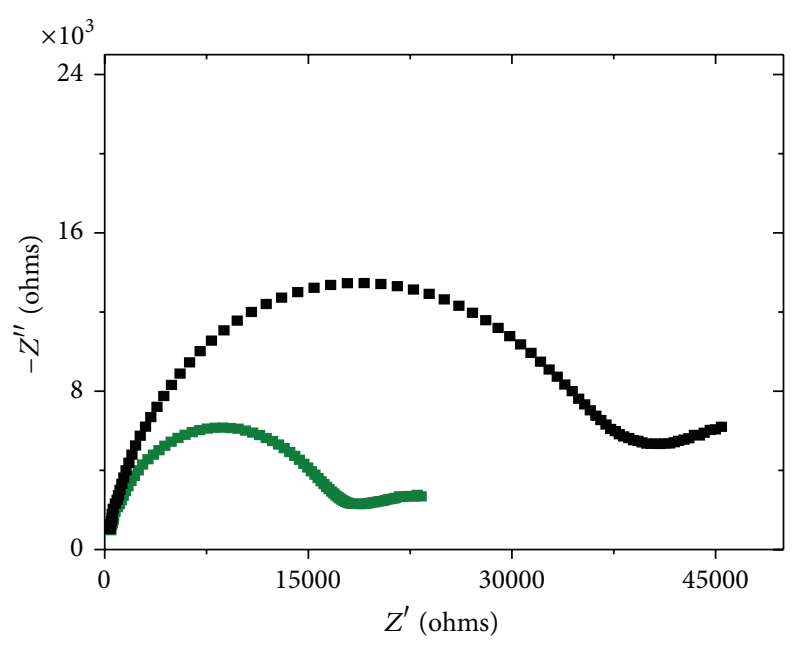

- $370^{\circ} \mathrm{C}$

- $400^{\circ} \mathrm{C}$

(c)

FIGURE 11: Spectrum of complex impedance of $\mathrm{LiNa}_{5} \mathrm{~K}_{3} \mathrm{Mo}_{11} \mathrm{As}_{3} \mathrm{O}_{45}$.

3.2. Structure Comparison. The studied phase reveals some structure affiliations with the phases found in the literature. In fact, the structures of $\mathrm{K}_{2} \mathrm{Mo}_{3} \mathrm{O}_{10}$ [19] and $\mathrm{K}_{2} \mathrm{Mo}_{4} \mathrm{O}_{13}$ [20] are one dimensional. Their basic units are formed by $\mathrm{MoO}_{6}$ octahedra and $\mathrm{MoO}_{5}$ bipyramids. The ribbons forms are helicoidal, as the ribbon forms of $\mathrm{LiNa}_{5} \mathrm{~K}_{3} \mathrm{Mo}_{11} \mathrm{As}_{3} \mathrm{O}_{45}$ compound. In the three-dimensional framework of $\mathrm{Na}_{6} \mathrm{Mo}_{5} \mathrm{P}_{2} \mathrm{O}_{23} \cdot 14 \mathrm{H}_{2} \mathrm{O}$ [21], we have found a cyclic group $\mathrm{Mo}_{5} \mathrm{O}_{21}$, but, in the structure of $\mathrm{LiNa}_{5} \mathrm{~K}_{3} \mathrm{Mo}_{11} \mathrm{As}_{3} \mathrm{O}_{45}$, the $\mathrm{Mo}_{5} \mathrm{O}_{20}$ group is linear. So, the structure of $\mathrm{Na}_{6} \mathrm{Mo}_{5} \mathrm{P}_{2} \mathrm{O}_{23} \cdot 14 \mathrm{H}_{2} \mathrm{O}$ differed from the structure of $\mathrm{LiNa}_{5} \mathrm{~K}_{3} \mathrm{Mo}_{11} \mathrm{As}_{3} \mathrm{O}_{45}$.

In the one-dimensional framework of $\mathrm{Na}_{2} \mathrm{AgMo}_{3} \mathrm{AsO}_{13}$ [4] and the framework of $\mathrm{Ag}_{12.4} \mathrm{Na}_{1.6} \mathrm{Mo}_{18} \mathrm{As}_{4} \mathrm{O}_{71}$ [1], there are two motifs similar to those found in $\mathrm{LiNa}_{5} \mathrm{~K}_{3} \mathrm{Mo}_{11} \mathrm{As}_{3} \mathrm{O}_{45}$ compound that are $\mathrm{Mo}_{3} \mathrm{O}_{14}$, formed by three $\mathrm{MoO}_{6}$ octahedra linked by sharing edges, and $\mathrm{Mo}_{3} \mathrm{AsO}_{17}$, composed by $\mathrm{Mo}_{3} \mathrm{O}_{14}$ motif and $\mathrm{AsO}_{4}$ tetrahedron.

3.3. Ionic Conductivity. The geometric data analysis shows that a few interstitial sites are adjacent to those occupied by cations (Figure 10). Furthermore, on the basis of the arrangement of cations in the one-dimensional framework, $\mathrm{LiNa}_{5} \mathrm{~K}_{3} \mathrm{Mo}_{11} \mathrm{As}_{3} \mathrm{O}_{45}$ compound could be a good ionic conductor. Figure 11 shows the spectrum of complex impedances of $\mathrm{LiNa}_{5} \mathrm{~K}_{3} \mathrm{Mo}_{11} \mathrm{As}_{3} \mathrm{O}_{45}$ in the various temperatures.

The radius of semicircles decreases when temperature increases signifying an ionic conduction with activated mechanism. The intercepts of the semicircles with the real 
TABLE 5: Bond valence sums.

\begin{tabular}{lc}
\hline Polyhedra & BVS \\
\hline $\mathrm{As}(1)-\mathrm{O}_{4}$ & 4.904 \\
$\mathrm{As}(2)-\mathrm{O}_{4}$ & 4.924 \\
$\mathrm{As}(3)-\mathrm{O}_{4}$ & 4.859 \\
$\mathrm{Mo}(1)-\mathrm{O}_{5}$ & 5.963 \\
$\mathrm{Mo}(2)-\mathrm{O}_{6}$ & 6.101 \\
$\mathrm{Mo}(3)-\mathrm{O}_{6}$ & 6.042 \\
$\mathrm{Mo}(4)-\mathrm{O}_{6}$ & 6.087 \\
$\mathrm{Mo}(5)-\mathrm{O}_{6}$ & 6.117 \\
$\mathrm{Mo}(6)-\mathrm{O}_{6}$ & 6.117 \\
$\mathrm{Mo}(7)-\mathrm{O}_{6}$ & 6.083 \\
$\mathrm{Mo}(8)-\mathrm{O}_{6}$ & 5.991 \\
$\mathrm{Mo}(9)-\mathrm{O}_{6}$ & 6.142 \\
$\mathrm{Mo}(10)-\mathrm{O}_{6}$ & 6.007 \\
$\mathrm{Mo}(11)-\mathrm{O}_{5}$ & 5.988 \\
$\mathrm{~K}(1)-\mathrm{O}_{8}$ & 0.927 \\
$\mathrm{~K}(2)-\mathrm{O}_{8}$ & 0.966 \\
$\mathrm{~K}(3)-\mathrm{O} 6$ & 0.976 \\
$\mathrm{Na}(1)-\mathrm{O} 8$ & 1.001 \\
$\mathrm{Na}(2)-\mathrm{O} 8$ & 0.905 \\
$\mathrm{Na}(3)-\mathrm{O}$ & 0.715 \\
$\mathrm{Na}(4)-\mathrm{O}$ & 1.052 \\
$\mathrm{Na}(5)-\mathrm{O}_{6}$ & 0.915 \\
$\mathrm{Li}-\mathrm{O}_{4}$ & 0.727 \\
\hline
\end{tabular}

TABLE 6: Conductivity value at various temperatures.

\begin{tabular}{lcc}
\hline $\mathrm{T}^{\circ}(\mathrm{C})$ & $|Z|(\Omega)$ & $\sigma=(e / s) / z\left(\Omega^{-1} \cdot \mathrm{cm}^{-1}\right)$ \\
\hline 255 & $4.50010^{5}$ & $2.1410^{-7}$ \\
280 & $2.55010^{5}$ & $3.7810^{-7}$ \\
310 & $1.40010^{5}$ & $6.9010^{-7}$ \\
340 & $8.65010^{4}$ & $1.1110^{-6}$ \\
370 & $4.10010^{4}$ & $2.3510^{-6}$ \\
400 & $2.05010^{4}$ & $4.7110^{-6}$ \\
\hline
\end{tabular}

axis give the estimated values of the material's resistances by using the Zview software [22]. The measured impedance can be modeled as that of an equivalent electrical circuit composed of a resistor $R$ connected in parallel with a nonideal capacitor usually known as constant phases elements CPE [23]. After determination of the resistance values at various temperatures and the dimensions of the sample, we have calculated the conductivity values (Table 6).

Figure 12 shows the variation of $\log \left(\sigma T\left(\mathrm{~S} \cdot \mathrm{K} \cdot \mathrm{cm}^{-1}\right)\right.$ versus $\left.10000 / T\left(\mathrm{~K}^{-1}\right)\right)$. The values of activation energies $\left(E_{a 1}\right.$ and $\left.E_{a 2}\right)$ of cations migration deduced from the slopes are equal to

(i) $E_{a 1}=0.559 \mathrm{eV}$ before $340^{\circ} \mathrm{C}$;

(ii) $E_{a 2}=0.871 \mathrm{eV}$ after $340^{\circ} \mathrm{C}$.

The change of activation energy is assigned to a change of cation migration process or a thermal transition.

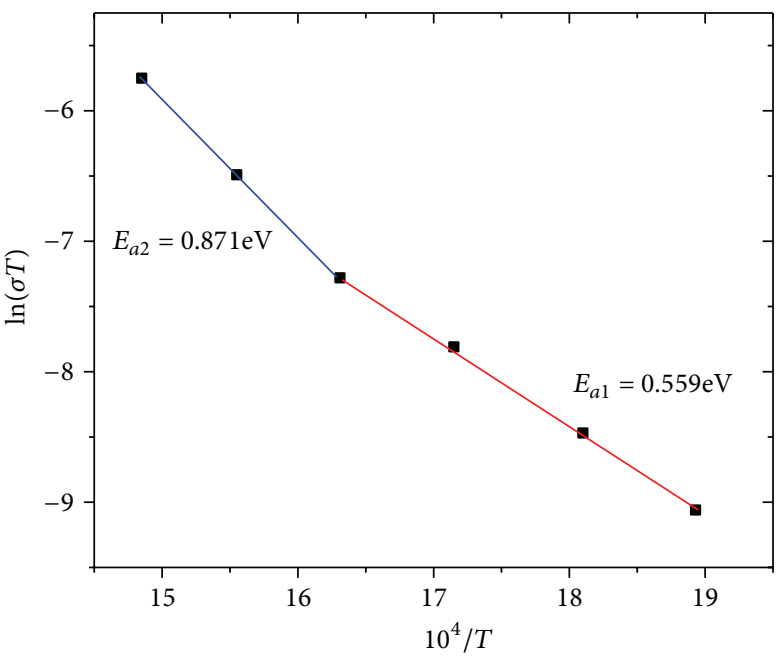

FIgURE 12: Variation of $\log \sigma T$ versus $10^{4} / T$.

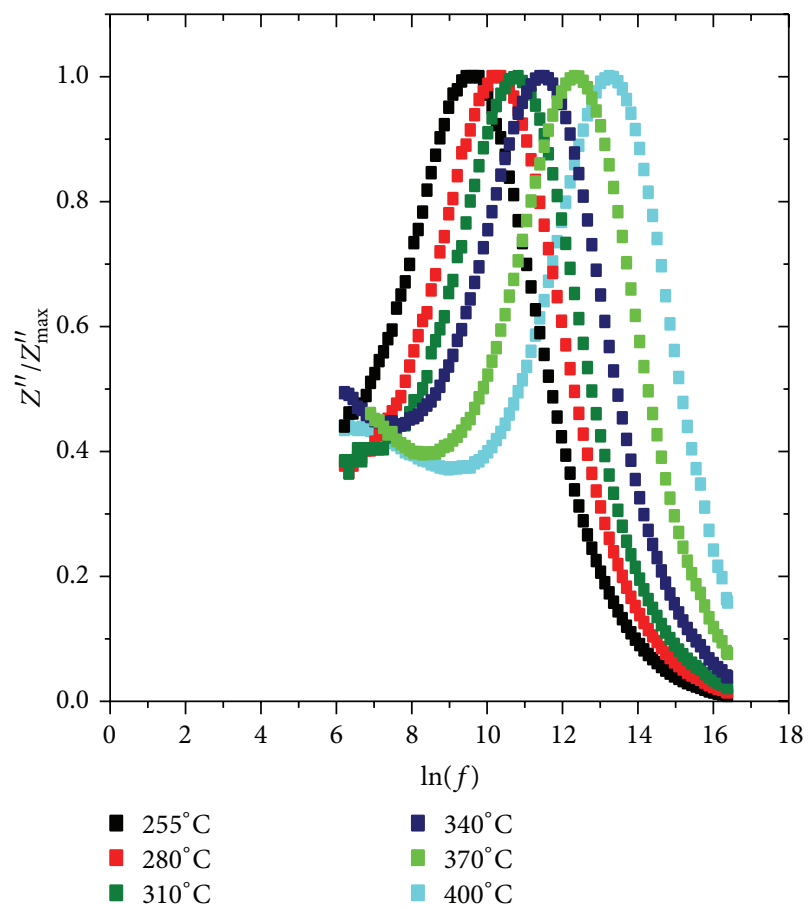

Figure 13: Variation of $Z^{\prime \prime} / Z_{\max }^{\prime \prime}$ versus $(\ln f)$.

Figure 13 shows the variation of the resistance imaginary part versus the relaxation frequency $\left(Z^{\prime \prime} / Z_{\max }^{\prime \prime}\right.$ versus $\left.(\ln f)\right)$. All curvatures in various temperatures have the same wide at midheight which is equal to $60.34 \mathrm{~Hz}(\ln f=4.1)$; this confirms that the variation of activation energy is not due to the change of cation migration process $[24,25]$. The DSC diagram in Figure 14 shows the change of baseline from $340^{\circ} \mathrm{C}$. Therefore, $\mathrm{LiNa}_{5} \mathrm{~K}_{3} \mathrm{Mo}_{11} \mathrm{As}_{3} \mathrm{O}_{45}$ compound is the subject of a thermal transition from this temperature and this is the real reason of change of activation energy. This compound shows a medium electric conductivity, compared with the compounds found in literature $[1,15,26]$. 


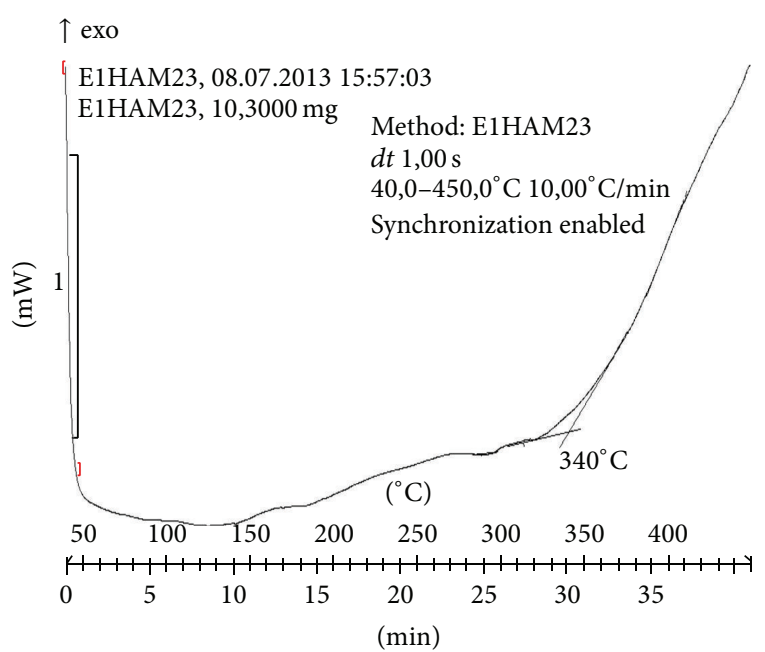

Figure 14: DSC diagram of $\mathrm{LiNa}_{5} \mathrm{~K}_{3} \mathrm{Mo}_{11} \mathrm{As}_{3} \mathrm{O}_{45}$ compound.

\section{Conclusion}

$\mathrm{LiNa}_{5} \mathrm{~K}_{3} \mathrm{Mo}_{11} \mathrm{As}_{3} \mathrm{O}_{45}$ compound was prepared by solid state reaction. The structure has been resolved by single crystal Xray diffraction and characterized by dispersive energy spectroscopy, powder X-ray diffraction, FTIR spectroscopy, and DSC. The compound crystallizes in the triclinic system (space group P-1) with the following unit cell parameters: $a=10.550$ (2) $\AA, b=11.723$ (2) $\AA, c=17.469$ (3) $\AA, \alpha=102.35(3)^{\circ}, \beta=87.61$ $(2)^{\circ}$, and $\gamma=111.03(3)^{\circ}$. This material has one-dimensional structure. The electrical properties are investigated using complex impedance spectroscopy. The conductivity value at $673 \mathrm{~K}$ is $4.71 \times 10^{-6} \mathrm{~S} \cdot \mathrm{cm}^{-1}$ and the activation energy value is $0.559 \mathrm{eV}$. $\mathrm{LiNa}_{5} \mathrm{~K}_{3} \mathrm{Mo}_{11} \mathrm{As}_{3} \mathrm{O}_{45}$ presents medium electric properties.

\section{Disclosure}

The CIF file corresponding to the studied structure has been deposited in the database of FIZ Karlsruhe no. CSD 426635.

\section{Conflict of Interests}

The authors declare that there is no conflict of interests regarding the publication of this paper.

\section{References}

[1] M. Hajji and M. F. Zid, "Synthesis, structure and ionic conductivity of the molybdenum arsenate: $\mathrm{Ag}_{12.4} \mathrm{Na}_{1.6} \mathrm{Mo}_{18} \mathrm{As}_{4} \mathrm{O}_{71}$," Solid State Sciences, vol. 14, no. 9, pp. 1349-1354, 2012.

[2] M. F. Zid, " $\mathrm{K}_{2} \mathrm{MoO}_{2}\left(\mathrm{MoO}_{2} \mathrm{As}_{2} \mathrm{O}_{7}\right)_{2}$, Acta Crystallographica C, vol. 52, pp. 2947-2949, 1996.

[3] R. Jouini, M. F. Zid, and A. Driss, "Disodium tris-(dioxidomolybdenum) bis-(diarsenate)," Acta Crystallographica E: Structure Reports Online, vol. 68, part 4, pp. i24-i25, 2012.

[4] H. Hamza, M. F. Zid, and A. Driss, " $\mathrm{NaAg}_{2} \mathrm{Mo}_{3} \mathrm{O}_{9} \mathrm{AsO}_{4}$ ", Acta Crystallographica E, vol. 66, no. 10, pp. i69-i70, 2010.
[5] A. J. M. Duisenberg, "Indexing in single-crystal diffractometry with an obstinate list of reflections," Journal of Applied Crystallography, vol. 25, no. 2, pp. 92-96, 1992.

[6] L. J. Farrugia, "WinGX and ORTEP for windows: an update," Journal of Applied Crystallography, vol. 45, no. 4, pp. 849-854, 2012.

[7] A. C. T. North, D. C. Phillips, and F. S. Mathews, "A semiempirical method of absorption correction," Acta Crystallographica Section A, vol. 24, pp. 351-359, 1968.

[8] G. M. Sheldrick, "A short history of SHELX," Acta Crystallographica A, vol. 64, no. 1, pp. 112-122, 2007.

[9] K. Brandenburg and M. Berndt, Diamond Version 2.1 Crystal Impact, GbR, Bonn, Germany, 2001.

[10] X’pert Highscore Plus, "Version 2.1 PANalytical B.V.," Almelo, Netherlands, 2004.

[11] K. Brandenburg, Diamond Version 3.2 Crystal Impact, Bonn, Germany, 1998.

[12] K. Nakamoto, Infrared and Raman Spectra of Inorganic and Coordination Compounds, Wiley-Interscience, New York, NY, USA, 3rd edition, 1978.

[13] R. Marzouki, A. Guesmi, M. F. Zid, and A. Driss, "Electrical properties and $\mathrm{Na}^{+}$mobility in $\mathrm{Na}_{4} \mathrm{Co}_{5.63} \mathrm{Al}_{0.91}\left(\mathrm{AsO}_{4}\right)_{6}$ material," Journal of Inorganic Chemistry, vol. 1, pp. 9-16, 2013.

[14] K. Viswanathan, V. Nayar, U. G. Aruldhas, and V. Ramakrishnan, "Vibrational spectra of $\mathrm{Te}(\mathrm{OH})_{6} \cdot 2 \mathrm{NH}_{4} \mathrm{H}_{2} \mathrm{PO}_{4} \cdot\left(\mathrm{NH}_{4}\right)_{2}$ $\mathrm{HPO}_{4}$," Journal of Solid State Chemistry, vol. 77, no. 2, pp. 394400, 1988.

[15] W. Frigui, F. B. Amor, M. F. Zid, A. Madini, and A. Driss, "Synthesis and physic-chemical study of Na0.5 K0.865 Mn3.435 $\left(\mathrm{AsO}_{4}\right)_{3}$ compound," Jordan Journal of Chemistry, vol. 6, pp. 295-305, 2011.

[16] H. Siebert, "Kraftkonstante und strukturchemie," Zeitschrift für Anorganische und Allgemeine Chemie, vol. 275, p. 225, 1954.

[17] B. Renner and G. Lehmann, "Correlation of angular and bond length distortions in $\mathrm{TO}_{4}$ units crystals," Zeitschrift für Kristallographie, vol. 175, pp. 43-59, 1986.

[18] D. Altermatt and I. D. Brown, "The automatic searching for chemical bonds in inorganic crystal structures," Acta Crystallographica, vol. B41, no. 4, pp. 240-244, 1985.

[19] B. M. Gatehouse and P. Leverett, "The crystal structure of dipotassium trimolybdate, $\mathrm{K}_{2} \mathrm{Mo}_{3} \mathrm{O}_{10}$; a compound with fiveco-ordinate molybdenum (VI)," Journal of the Chemical Society A, pp. 1398-1405, 1968.

[20] K. Eda, K. Chin, N. Sotani, and M. S. Whittingham, " $\mathrm{K}_{2} \mathrm{Mo}_{4} \mathrm{O}_{13}$ phases prepared by hydrothermal synthesis," Journal of Solid State Chemistry, vol. 177, no. 3, pp. 916-921, 2004.

[21] B. Hedman, "Multicomponent polyanions. 16. The molecular and crystal structure of $\mathrm{Na}_{6} \mathrm{Mo}_{5} \mathrm{P}_{2} \mathrm{O}_{23}\left(\mathrm{H}_{2} \mathrm{O}\right)_{14}$, a compound containing sodium-coordinated pentamolybdodiphosphate anions," Acta Crystallographica B , vol. 24, pp. 3083-3090, 1977.

[22] D. Johnson, Zview version 3.1c, Scribner Associates, 1990.

[23] A. K. Jonscher, "The interpretation of non-ideal dielectric admittance and impedance diagrams," Physica Status Solidi A, vol. 32, no. 2, pp. 665-676, 1975.

[24] A. Kumar, B. P. Singh, R. N. P. Choudhary, and A. K. Thakur, "A.C. impedance analysis of the effect of dopant concentration on electrical properties of calcium modified $\mathrm{BaSnO}_{3}$," Journal of Alloys and Compounds, vol. 394, no. 1-2, pp. 292-302, 2005. 
[25] P. Muralidharan, M. Venkateswarlu, and N. Satyanarayana, "Sol-gel synthesis, structural and ion transport studies of lithium borosilicate glasses," Solid State Ionics, vol. 166, no. 1-2, pp. 27-38, 2004.

[26] N. Ouerfelli, A. Guesmi, D. Mazza, A. Madani, M. F. Zid, and A. Driss, "Synthesis, crystal structure and mono-dimensional thallium ion conduction of $\mathrm{TlFe}_{0.22} \mathrm{Al}_{0.78} \mathrm{As}_{2} \mathrm{O}_{7}$," Journal of Solid State Chemistry, vol. 180, no. 4, pp. 1224-1229, 2007. 

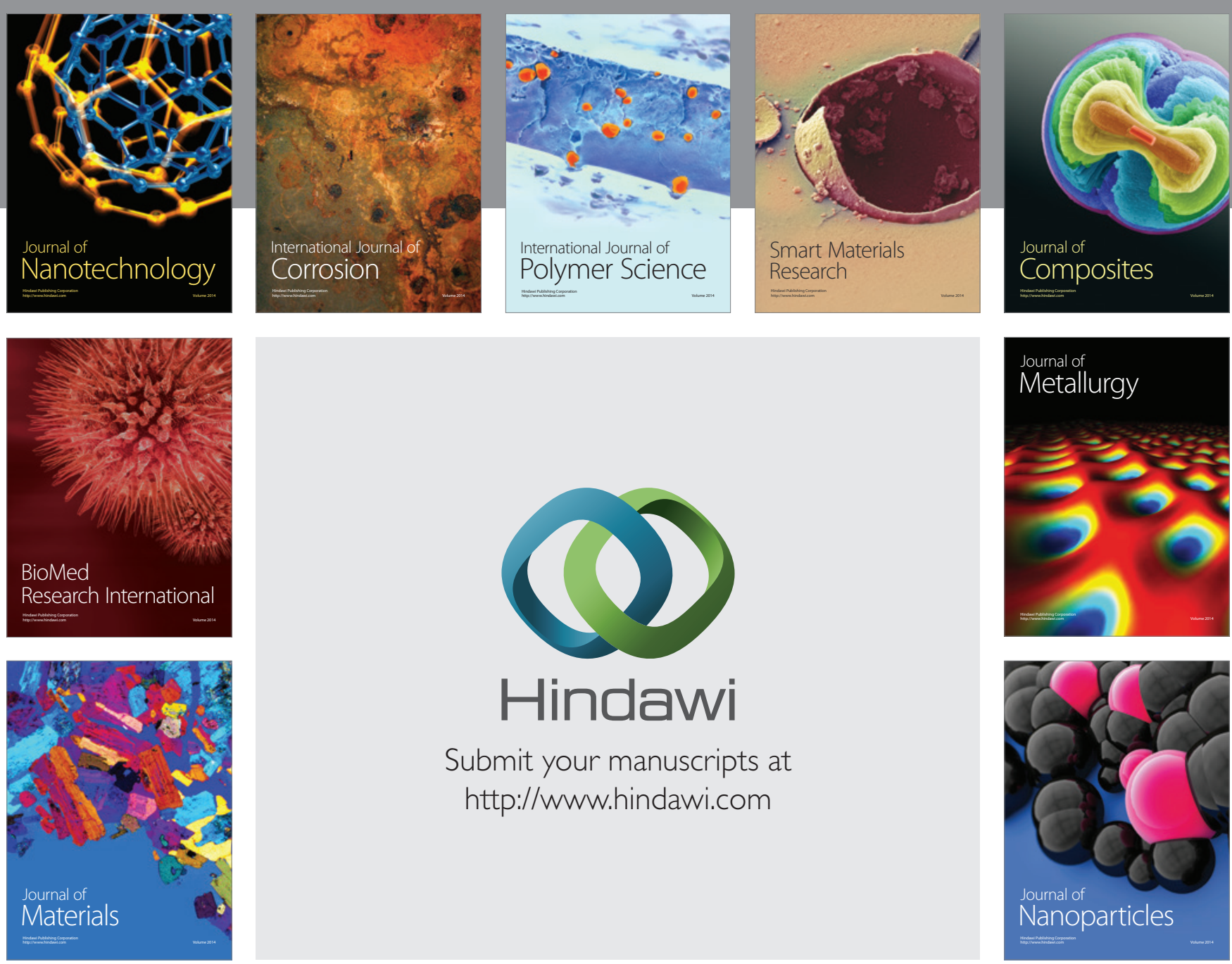

Submit your manuscripts at http://www.hindawi.com
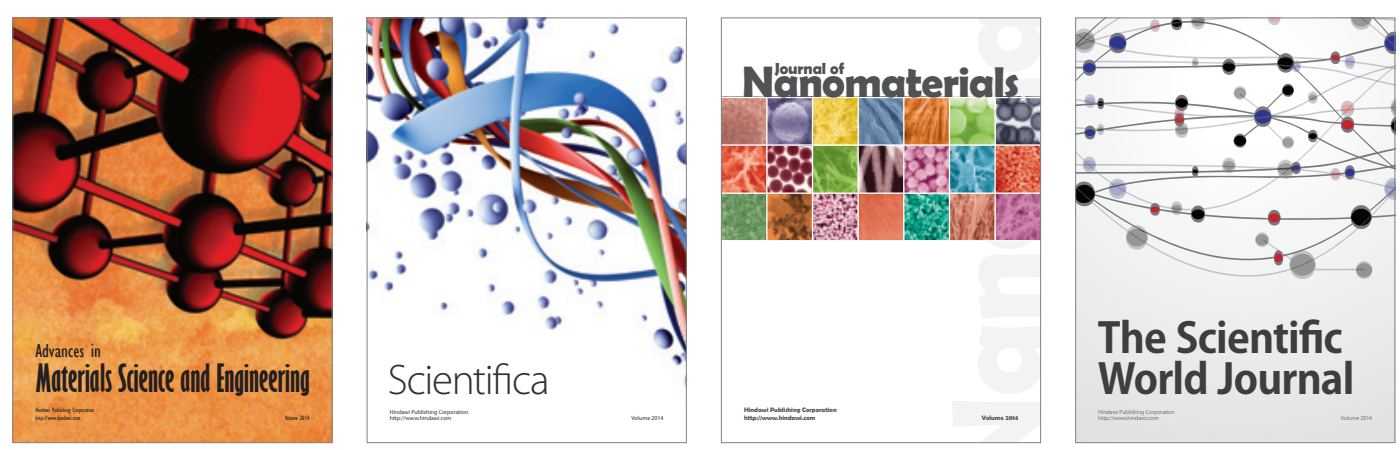

\section{The Scientific World Journal}
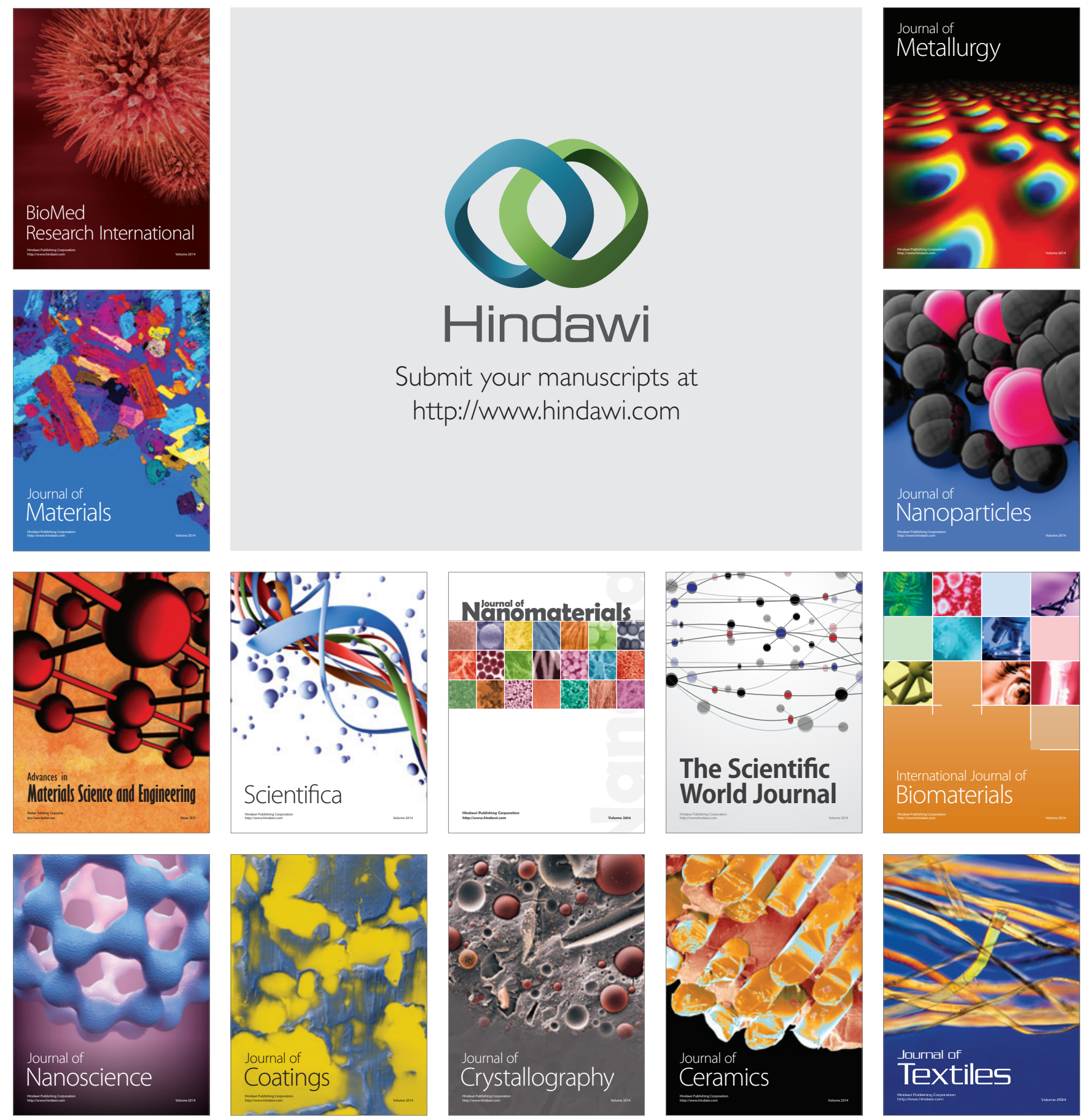